СТАН ДЕРЕВНИХ НАСАДЖЕНЬ НА ТЕРИТОРІЇ ШКОЛИ №1

М. ВИШГОРОДА (КИЇВСЬКА ОБЛ.)

О. В. ЗІБЦЕВА, кандидат сільськогосподарських наук, доцент

Національний університет біоресурсів і природокористування Украӥни

E-mail: stplut@yandex.ua

Анотація. Досліджено стан $i$ декоративність деревних та чагарникових насаджень на території школи в центральній частині малого міста Вишгорода. Встановлено залежності між окремими біометричними характеристиками і станом деревних рослин.

Ключові слова: шкільна територія, деревні і чагарникові насадження, вік, стан

Максимально ефективно виконувати свої функції, зокрема санітарногігієнічні, спроможні лише зелені насадження, які перебувають у доброму стані $[1,4]$. Тому, визначення реального стану деревних і чагарникових насаджень, виявлення залежностей від впливу різноманітних факторів та пошук шляхів щодо його покращання залишаються надзвичайно актуальними.

Озеленені території за умов раціональної організації суттєво впливають на найважливіші показники якості навколишнього середовища. Повне виявлення всіх функцій рослин для підвищення їх здатності максимально покращувати навколишнє середовище в існуючому екологічному оточенні $€$ важливою задачею для створення сприятливих умов у містах [5].

Зелені насадження на шкільній території мають особливе значення. Крім загальних для зелених насаджень функцій, тут вони відіграють ще й пізнавальну роль. Крім того, результати останніх досліджень свідчать про те, що зелені насадження впливають на когнітивний розвиток дітей [6]. Автори вважають, що високий рівень озеленення (на території в межах школи і в 50 м від школи) суттєво покращує дитячу пам'ять та уважність, з цієї ж причини діти у лісових школах більш активні та вмотивовані. 
Мета дослідження - визначити й проаналізувати стан і декоративність деревних та чагарникових насаджень на території об'єкта обмеженого користування - загальноосвітньої середньої школи № 1 у центральній частині малого міста.

Матеріали і методика дослідження. Предмет досліджень - деревні i чагарникові насадження на шкільній території у центральній частині м. Вишгорода. Для аналізу були використані матеріали інвентаризації насаджень, проведеної нами влітку 2015 року і наведені у [2]. Стан насаджень визначався за п'ятибальною шкалою візуальної оцінки, декоративність - за трибальною [5]. Були задіяні дендрологічні, біометричні, таксаційні та статистичні методи досліджень.

Результати досліджень та їх обговорення. Встановлено, що деревночагарникові насадження на шкільній території налічують 28 видів рослин, у тому числі 20 видів дерев і 8 видів чагарників. Кількісно переважають деревні рослини Ulmus laevis L., Thuja occidentalis L., Tilia cordata Mill., Acer platanoides L., Populus pyramidalis Rozier., а серед чагарників Ligustrum vulgare L., Spiraea japonica L., S. Douglasii Hook. та Amorpha fruticosa L. Біометрична характеристика найбільш поширених видів наведена у таблиці.

Аналіз даних інвентаризації показав, що на шкільній території переважають тридцяти- і шестидесятирічні деревні рослини (рис. 1), на які в сумі припадає понад 75 \% екземплярів.

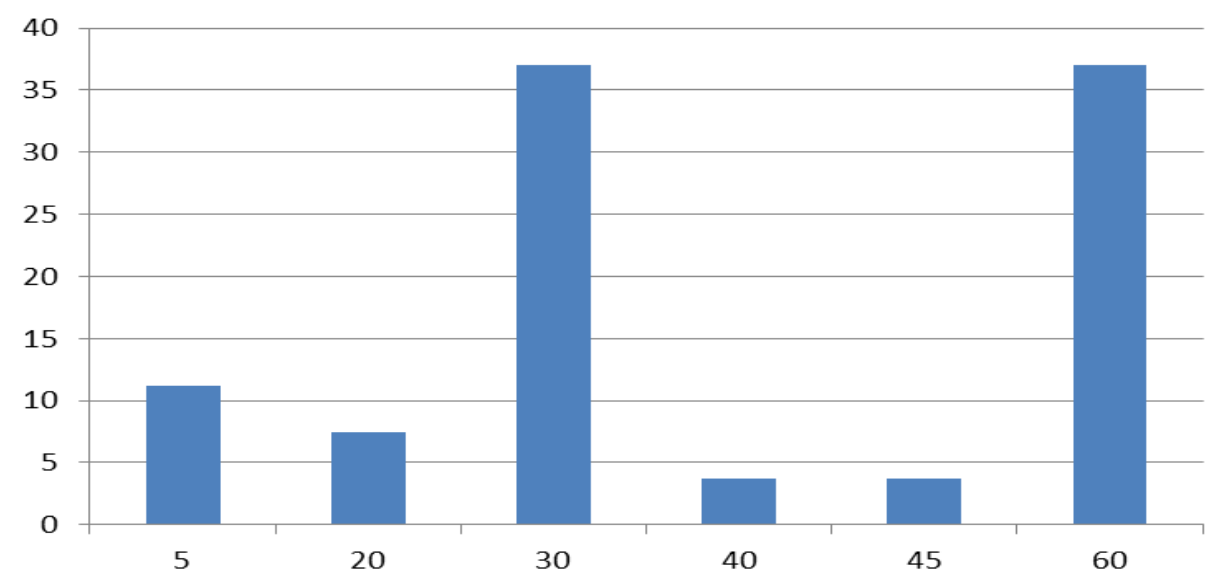

Рис.1. Розподіл деревних насаджень за віком, \% 
Характеристика найбільш поширених деревних i чагарникових видів на території ЗОШ № 1 м. Вишгорода

\begin{tabular}{|l|c|c|c|c|c|}
\hline \multirow{2}{*}{\multicolumn{1}{|c|}{ Вид }} & \multicolumn{5}{|c|}{ Показник, М \pm т } \\
\cline { 2 - 6 } & $\begin{array}{c}\text { Вік, } \\
\text { років }\end{array}$ & $\begin{array}{c}\text { Висота, } \\
\text { м }\end{array}$ & $\begin{array}{c}\text { Діаметр, } \\
\text { см }\end{array}$ & $\begin{array}{c}\text { Стан, } \\
\text { бал }\end{array}$ & $\begin{array}{c}\text { Декоративність, } \\
\text { бал }\end{array}$ \\
\hline Ulmus glabra & $58 \pm 0,7$ & $8 \pm 0,1$ & $38 \pm 1,1$ & $3,0 \pm 0,03$ & $1,8 \pm 0,04$ \\
\hline Thuja occidentalis & 40 & $3 \pm 0,5$ & $9 \pm 1,0$ & $2,8 \pm 0,2$ & $1,4 \pm 0,24$ \\
\hline Tilia cordata & $41 \pm 4,2$ & $7 \pm 0,6$ & $34 \pm 6,0$ & $2,5 \pm 0,14$ & $1,5 \pm 0,14$ \\
\hline Acer platanoides & $55 \pm 3,1$ & $9 \pm 0,6$ & $54 \pm 5,1$ & $2,7 \pm 0,14$ & $1,6 \pm 0,15$ \\
\hline Populus pyramidalis & 60 & 12 & 60 & 2 & 1 \\
\hline Betula pendula & $55 \pm 5$ & $10 \pm 0,5$ & $60 \pm 4$ & 2 & 1 \\
\hline Robinia pseudoacacia & $42 \pm 9,5$ & $8 \pm 1,7$ & $43 \pm 11$ & $2,8 \pm 0,54$ & $1,2 \pm 0,2$ \\
\hline Juglans regia & $17 \pm 1,7$ & $4 \pm 0,6$ & $11 \pm 0,7$ & $2,3 \pm 0,33$ & 1 \\
\hline Acer pseudoplatanus & $49 \pm 7,2$ & $8 \pm 0,6$ & $42 \pm 11,4$ & $2,5 \pm 0,29$ & $1,5 \pm 0,29$ \\
\hline Malus domestica & 30 & 3 & 14 & 3 & 2 \\
\hline
\end{tabular}

Кращим станом і декоративністю відзначаються старші, - сорока- i шістдесятирічні насадження, зокрема екземпляри Populus pyramidalis, Betula pendula, Robinia pseudoacacia, Thuja occidentalis, гіршим - двадцяти- i сорокап'ятирічні (рис. 2), у тому числі старі дерева Malus domestica у шкільному саду.

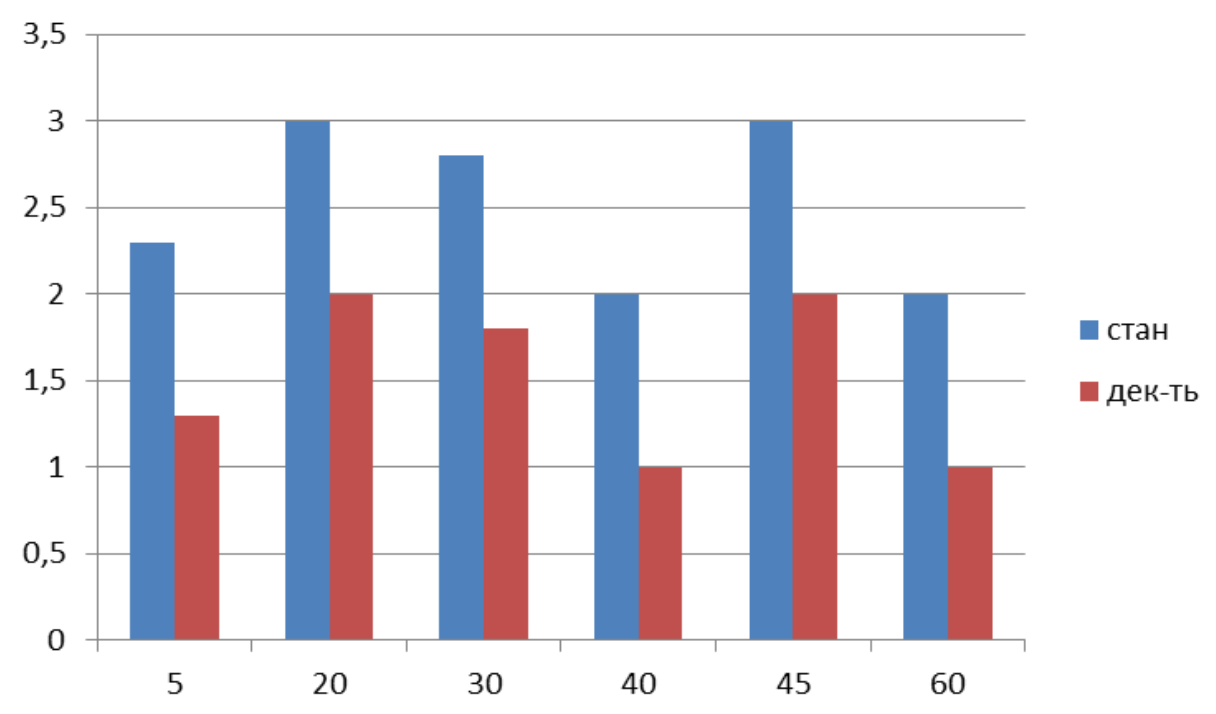

Рис. 2. Стан і декоративність деревних насаджень різного віку, бали 
Порівняно низький стан Ulmus glabra, що відповіає задовільному, пояснюється їх віком (понад 50 років) і зростанням у загущених рядових посадках по периметру ділянки.

На рисунках 3 і 4 вистроєні ряди найбільш поширених на шкільній території деревних рослин у порядку збільшення їх середнього віку та висоти.

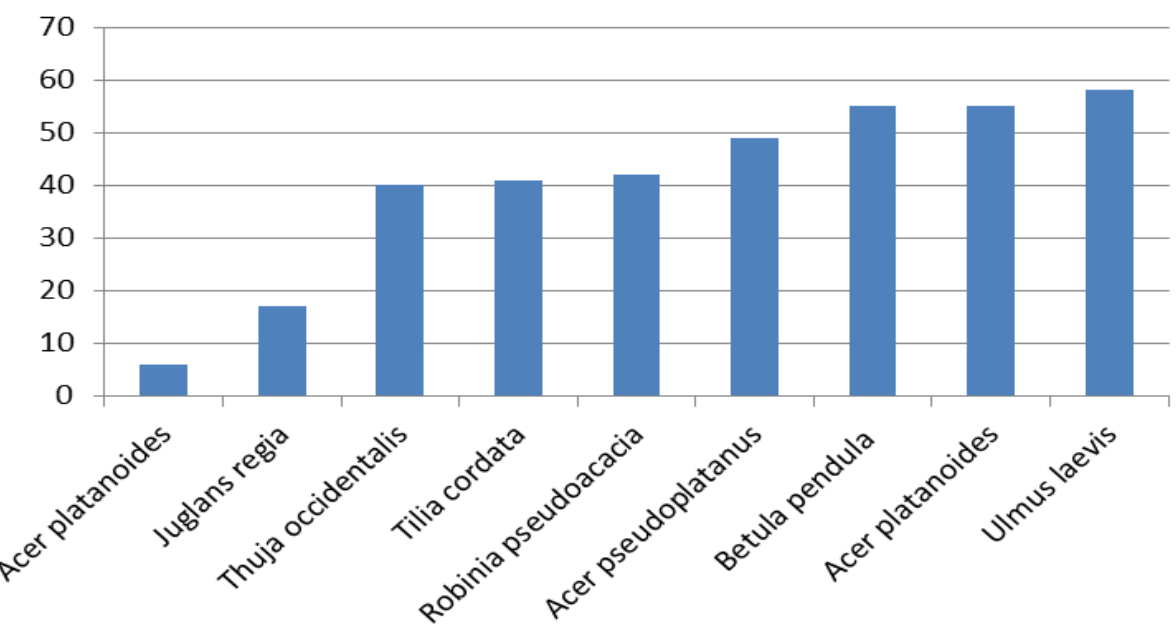

Рис. 3. Середній вік деревних насаджень у розрізі видів

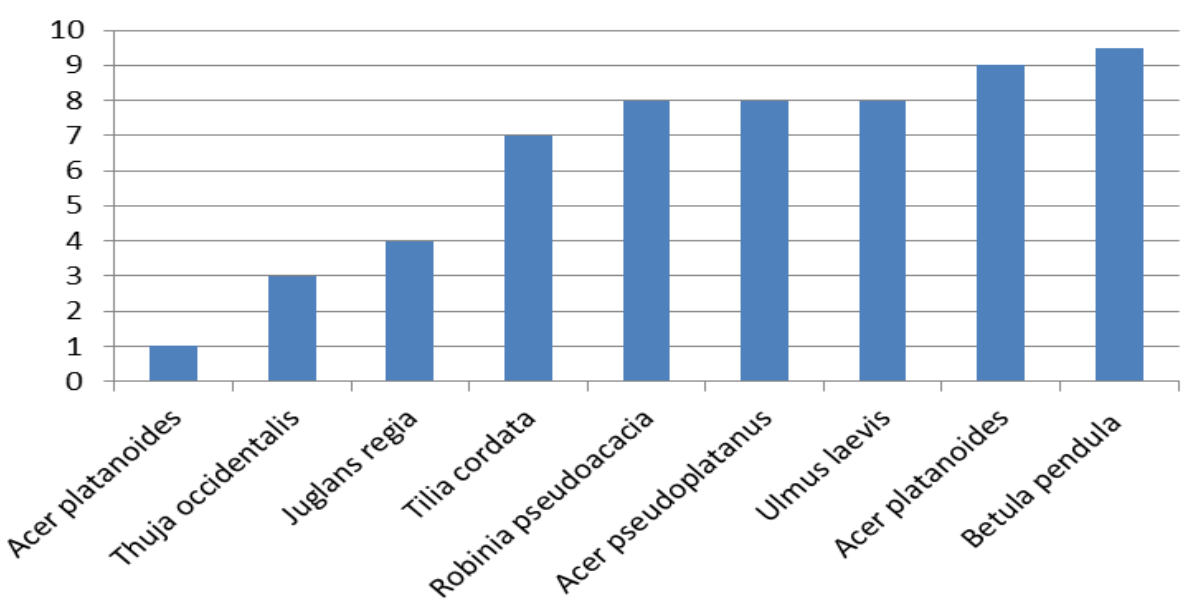

\section{Рис.4. Середня висота деревних видів на шкільній території}

Кількісно переважають середньовікові екземпляри дерев і дерева старшого віку. Середня висота насаджень суттєво коливається в розрізі видів і становить від 3 (Thuja occidentalis, плодові) до понад 12 м (Populus pyramidalis). Найбільш високими є старші дерева Populus pyramidalis, Ulmus 
glabra, Acer pseudoplatanus, A. platanoides, які ростуть у рядових периметральних посадках вздовж ділянки.

Виявлена середня негативна кореляція між середнім балом стану деревних видів та їх середнім діаметром на висоті грудей $(-0,491)$, а також їх висотою $(-0,552)$, високий кореляційний зв'язок $(0,827)$ - між станом і декоративністю деревних рослин.

\section{Висновки}

Встановлено, що деревно-чагарникові насадження на шкільній території налічують лише 28 видів, що свідчить про те, що пізнавальна функція зелених насаджень використовується слабо. Кращим (на рівні доброго) станом i вищою декоративністю характеризуються дерева Populus pyramidalis, Betula pendula, Juglans regia. Гіршим станом (на рівні задовільного) і нижчою декоративністю відзначаються Ulmus glabra, Malus domestica.

У насадженнях переважають тридцяти- i шестидесятирічні деревні рослини. Кращим станом i декоративністю відзначаються сорока- i шістдесятирічні деревні рослини, гіршим - двадцяти- і сорокап'ятирічні. Середній стан деревних насаджень на шкільній території близький до задовільного.

\section{Список літератури}

1. Авдеева Е. В. Природный каркас - основа устойчивого развития урбанизированных территорий [Текст] / Е. В. Авдеева // Проблемы озеленения городов: сб. ст. - Вып. 10. - Москва, 2004. - С.18-20.

2. Зібцева О. В. Видовий склад деревно-чагарникових насаджень на території школи у м. Вишгороді Київської обл. [Електронний ресурс] / О. В. Зібцева. Наукові доповіді НУБіП України № 3 (600) 2016. - Режим доступу: http://journals.nubip.edu.ua/index.php/Dopovidi/article/view/6845

3. Мониторинг состояния древесных насаждений на некоторых объектах озеленения в центральной части города Мурманска [Електронний ресурс] / О. Б. Гонтарь, Е. А. Святковская, Н. Н. Тростенюк, Н. М. Коробейникова, Е. П. Шлапак, О. Ю. Носатенко - Режим доступу: https://www.2013 3621 -625.pdf

4. Филиппова А. В. К вопросу организации эффективных насаждений древесных пород в условиях городской среды [Електронний ресурс] / А. В. Филлипова, М. В. Рябухина // Ученые записки Таврического 
национального университета им. В. И. Вернадского. Серия «Биология, химия». - Том 27 (66). - №5. - 2014. - С. 160-164. - Режим доступу: http://snbiolchem.crimea.edu/

5. Якушина Э. И. Древесные растения в озеленении Москвы / Э. И. Якушина. - М.: Наука, 1982. - 158 с.

6. Expert reaction to exposure to green spaces at school and cognitive development in primary schoolchildren [Електронний ресурс] / June 15, 2015. Режим доступу: sciencemediacentre.org

\section{References}

1. Avdeeva E. V. (2004). Prirodniy karkas - osnova ustoychivogo razvitiya urbanizirovannih territoriy [Natural frame - the basis of sustainable development of urban areas]. Problemi ozeleneniya gorodov - Problems of urban greening. Moscow, Vol.10, 18-20.

2. Zibtseva O.V. (2016). Vidoviy sklad derevno-chagarnikovih nasadzhen' na territorii shkoli u m. Vishgorodi Kiyvskoyi obl. [Species composition of tree and bush plantations at the school territory in Vyshgorod t., Kyiv region]. Naukovi dopovidi NUBiP- Scientific reports NUBiP, 3 (600). Available at: http://journals.nubip.edu.ua/index.php/Dopovidi/article/view/6845

3. Gontar O. B., Svyatkovskaya E. A., Trostenyuk N. N. and others Monitoring sostoyaniya drevesnih nasazhdeniy na nekotorih ob'ektah ozeleneniya $\mathrm{v}$ tsentralnoy chasti Murmanska [Monitoring of tree plantations on some landscaping facilities in the central part of Murmansk city]. Available at: https://www.2013 3621 625.pdf

4. Fylyppova A. V., Ryabuhyna M. V. (2014). K voprosu organizatsii effectivnih nasazhdeniy drevesnih porod $\mathrm{v}$ usloviyah gorodskoy sredi [On the question of organization of effective planting of trees in the urban environment]. Uchenie zapiski Tavricheskogo natsionalnogo universiteta im. V.I. Vernadskogo. Series "Biology, Chemistry", vol. 27(66), 5, 160-164. Available at: http://snbiolchem.crimea.edu/

5. Yakushina E. I. (1982). Drevesnie rasteniya v ozelenenii Moskvi [Tree plants in gardening of Moscow]. Moscow: Nauka, 158.

6. Expert reaction to exposure to green spaces at school and cognitive development in primary schoolchildren. Available at: http://www. sciencemediacentre.org/ (accessed 15 June 2015).

\section{СОСТОЯНИЕ ДРЕВЕСНЫХ НАСАЖДЕНИЙ НА ТЕРРИТОРИИ ШКОЛЫ № 1 Г. ВЫШГОРОДА (КИЕВСКАЯ ОБЛ.) О. В. Зибцева}

Аннотация. Изучено состояние $и$ декоративность древесных $u$ кустарниковых насаждений на территории школь в центральной части малого г. Вышгорода. Установлены зависимости между отдельными биометрическими показателями и состоянием древесных растений. 
Ключевые слова: икольная территория, древесные и кустарниковые насаждения, возраст, состояние

\title{
STATE OF TREE PLANTATIONS ON TERRITORY OF SCHOOL N 1 IN VYSHGOROD T. (KYIV REGION) \\ O. V. Zibtseva
}

\begin{abstract}
The state and ornamental state of tree and shrub plantings on school territory in downtown of Vyshgorod has been investigated. Corelations between biometrical items and state of tree plants were defined.
\end{abstract}

Key words: school territory, tree and shrub plantations, age, state 